\title{
WOMEN IN MALAYSIAN SEAWEED INDUSTRY: MOTIVATIONS AND IMPACTS
}

\section{Velan Kunjuraman ${ }^{1 *}$, Aisah Hossin ${ }^{2}$ and Rosazman Hussin ${ }^{2}$}

${ }^{1}$ Faculty of Hospitality, Tourism and Wellness, Universiti Malaysia Kelantan, Kelantan, MALAYSIA

${ }^{2}$ Borneo Institute for Indigenous Studies (BorIIS), Faculty of Humanities, Art and Heritage, Universiti Malaysia Sabah, Sabah, MALAYSIA

"Corresponding author: velan1199@gmail.com

Published online: 20 November 2019

To cite this article: Kunjuraman, V., Aisah Hossin and Rosazman Hussin. 2019. Women in Malaysian seaweed industry: Motivations and impacts. Kajian Malaysia 37(2): 49-74. https://doi. org/10.21315/km2019.37.2.3

To link to this article: https://doi.org/10.21315/km2019.37.2.3

\begin{abstract}
Malaysian development plans have often emphasised the importance of issues relating to women's position in the society. In the context of the seaweed industry in Sabah, East Malaysia, a capacity building programme has been initiated by the government agencies, which is known as the Mini Estate System (MES) and the Cluster System (CS) with the aim to transform the conventional seaweed cultivation activity to a new approach based on scientific technology. In this programme, local seaweed cultivators use modern technology to improve their skills and knowledge. However, with regard to women's participation in the seaweed industry, few new capacity building programmes have been introduced. Therefore, this article analyses women's participation in the seaweed cultivation activity implemented through MES and CS in two islands, Selakan and Bum Bum, in the District of Semporna, Sabah. The qualitative research approach with indepth interviews and participant observation were applied in this study. The results of the study indicate that women participants through MES and CS received few key benefits. The benefits gained by the women include: (1) enhancement of knowledge and skills of a new approach for seaweed cultivation activity, (2) improvement of monthly income, (3) enhanced awareness in their involvement in multiple business opportunities, and (4) increase of systematic management at the workplace by attending various workshops and seminars. In terms of policy and practical implications, this study suggests that continuous support from various stakeholders including government and private companies are vital in order to
\end{abstract}


Velan Kunjuraman et al.

sustain the seaweed industry in Malaysia, as well as to enhance rural community development, especially among women.

Keywords: women, seaweed industry, participation, stakeholders, empowerment

\section{INTRODUCTION}

The United Nation's Sustainable Development Goals (SDGs) acknowledge that women play an integral role in development projects and women make up the most important group for engagements. Millennium Development Goals notably recognised women's well-being with its fifth goal, which is to ensure their development is on par with men (United Nations 2016). To date, women participation in industries is the focal point in many countries and agencies pertaining to women development. Such initiatives from all parties highlight the importance of women's participation in development projects and at the same time, provides social, economic, political and environmental benefits. In this regard, women's involvement in the economic sector, as indicated by the United Nations' website, is less than significant; for example, women in Northern Africa hold less than one in five paid jobs in the non-agricultural sector. In addition, the proportion of women in paid employment beyond the agriculture sector has only increased $6 \%$ in 15 years, from $35 \%$ in 1990 to $41 \%$ in 2015 (United Nations 2016). However, women's contribution in agricultural sectors is still acknowledged and welcomed (Begum and Yasmeen 2011). In the context of seaweed cultivation, the role of women is evident as they contribute to the success of seaweed production and cultivation, as well as social development. Their role has been widely discussed in previous literature with different geographical setting such as India, Indonesia, Malaysia, Philippines, Tanzania and the Solomon Islands (Msuya 2006; 2007; Bindu 2010; Cai, Hishamunda and Ridler 2013; Neish 2013; Hurtado 2013; Msuya 2013; Kronen 2013; Krishnan and Narayanakumar 2013; Robledo, Gasca-Leyva and Fraga 2013; Hossin et al. 2013; Sraboni et al. 2014; Ghosh and Ghosh 2014; Eranza et al. 2015; Rosazman et al. 2015).

In Malaysia, women's contributions towards the country's development are evident and increasingly recognised. This can be seen in terms of human resource development where women in Malaysia have contributed as employees, consumers and entrepreneurs providing employment opportunities (Chee et al. 2012). In addition, the Malaysian government has emphasised participation by women in development projects through several government agencies such as the State Economic Development Corporation (SEDC), Ministry for Women, Family and Community Development, Ministry of Rural and Regional Development, Department of Community Development (KEMAS) and Department of Agriculture 
(DOA). These agencies are responsible to assist these women overcoming hardships by recognising women's roles and developing their skills by providing relevant workshops and organising campaigns.

Women's participation in development projects are also addressed by the Malaysian government policies. There are few aspects that need to be pursuit in terms of agricultural sectors especially in the context of seaweed industry. Studies pertaining to participation by women in the seaweed industry in Malaysia have neglected the topic and missing link in the previous literature. Msuya $(2006 ; 2007)$ proposed that women participation in the seaweed industry is important to enhance the productivity of the industry. The study, which was conducted in Zanzibar, showed that more than $90 \%$ of seaweed cultivators are women. Similarly, in Malaysia, women dominate the seaweed industry even though the majority of the work force are men and they play an important role to enhance seaweed production and generate revenues. Thus, women's contributions to the advancement of the seaweed industry should be increased through capacity building programmes and documentation. In this regard, this study has proposed four research questions namely:

1. Are women really considered as an important manpower in the seaweed industry in Malaysia, do government policies, especially in agricultural sectors recognise women participation?

2. What are the factors that contribute to women's involvement in the Malaysian seaweed industry?

3. What are the capacity building programmes available for women in the Malaysian seaweed industry?

4. What are the implications of the government's interventions programme to women's well-being?

In light of the above, this study aims to fill a void in the literature on seaweed cultivation and to provide insights to relevant stakeholders engaged in the Malaysian seaweed industry. Through this case study, which was conducted in Semporna, this study explores the factors influencing women's participation in the seaweed industry and the implications of government-led seaweed interventions on women's participation. This study also proposes that future seaweed researchers could consider the findings of this study and guide them to embark on future studies on seaweed in the contexts of developed and developing countries. 


\section{WOMEN'S EMPOWERMENT}

The concept of empowerment can be multidimensional and often carries different meanings when employed by different researchers in a specific context. Choo and Williams (2014) mentioned that the word "empowerment" can be indicated by referring to its root of origin word "power", and often associated with another descriptive words such as over, to, with and within. Several examples of the usage of power concept have been documented by Rowlands (1997), Gaventa (2006), and Choo and Williams (2014). According to Gaventa (2006), "power over" is referred to the ability or capability of the influential party to affect the actions and thoughts of the powerless. This can be described where the situation - the more power one has, the less power the other has. In addition, the sense of domination exists in this context. Next, power to refers to the situation when the person or organisation intends to organise and change the existing hierarchies. Meanwhile, power with refers to a situation where a person or a group is working together with the intention to increase power from collective actions. For instance, a women group in agricultural sector gained power in the decision-making process with the help from the fellow women and men as well as external stakeholders who supported their effort. Power within can be understood as a situation where an individual or group gained consciousness and are informed about any development projects associated to their lives. In the development context, empowerment is often linked to the power over definition (Rowlands 1997) - "that women should somehow be empowered to participate within the economic and political structures of society" (Choo and Williams 2014, 17). The working definition concepts power over, to, with and within and their implications to understand the empowerment concept has been compiled by Rowlands (1997).

It is observed that empowerment has many dimensions and depends on the context to use it. Interestingly, from a feminist perspective, "power over" has been criticised as a promotion of dynamics in oppression and internalised oppression (Choo and Williams 2014). Thus, the notion of power over in the definition of empowerment is not relevant to be applied in women studies. Based on the above description of the empowerment concept, the "power to" and "power within" elements in the empowerment concept is deemed appropriate to be applied in this study whereby the women in seaweed cultivation have received positive impacts on economic and social empowerment such as income generation, access to new technology in seaweed production and increased awareness and knowledge in seaweed cultivation activities in Semporna, Sabah. 


\section{WOMEN PARTICIPATION IN SEAWEED CULTIVATION}

At present, seaweed has been considered as an important commodity for import and export purposes all around the world. Its cultivation has brought many economic benefits. The first seaweed farm was opened in 1969 by Marine Colloids Inc. and University of Hawaii Professor, Maxwell Doty in the province of Tawi-Tawi in the south of Philippines (Valderrama et al. 2013). The success of seaweed cultivation in the Philippines garnered the interest of neighbouring countries like Indonesia and Malaysia with participation by the communities within these regions. In Indonesia, the seaweed production has increased from 214,505.9 metric tons of dried seaweed in 2008, and by 2012 it tripled to $651,485.4$ metric tons, positioning itself as one of the leading seaweed exporters (Eranza et al. 2015). Compared to Indonesia, Malaysia is perceived as one of the seaweed producers and expected to continue its production in sustainable ways. In terms of value, in 2013, the seaweed production from Sabah, Malaysia amounted to $28 \%$ by volume $(33,210$ metric ton) and 3\% (RM198.93 million). This value is based on the total marine aquaculture production. In fact, the seaweed production from Sabah recorded to be increased slightly by volume in 2013 to 110.0 metric tons compared to 2012 (Safari 2015). Such scientific record clearly indicates that the seaweed industry in Malaysia has great potential to be developed, and attentions from the relevant stakeholders are still needed even though few attempts were made to sustain the industry. Based on the previous literature, stakeholders' involvement especially coastal rural communities in seaweed cultivation play an important role in sustaining the seaweed industry in many countries and increase the growth of seaweed production especially the extraction of carrageenan, which is used in many commercial products.

Seaweed cultivation not only helps the economic development of a country but it also plays a socially important role in the development of the rural community. Valderrama et al. (2013) claimed that the socio-economic impacts of carrageenan seaweed cultivation on coastal communities have been overwhelmingly positive. In this regard, seaweed cultivation by the coastal communities is generally easy as it fits into their daily lifestyle as seen in terms of production model preferences, such as small-scale, family operations over corporate, plantation-style farms, the generation of substantial employment relative to other forms of aquaculture through seaweed cultivation. Consequently, many researchers all around the world have carried out studies on the socio-economic impacts of seaweed cultivation on coastal communities. Most studies claim that seaweed cultivation activities have brought positive social, economic and environmental impacts to the local 
community. In this section, a few of the impacts based on the relevance to the present study are discussed. It is worth to note that studies on seaweed cultivation from the social science perspectives are needed and insights from those studies could provide guidance for future researchers to embark on more studies pertaining to seaweed cultivation and livelihood of people in the coastal area. In addition, it is also hoped that the relevant stakeholders of the seaweed industry could use new insights on the issues to introduce and develop policies to achieve positive results.

Members of coastal communities, especially women, largely dominate the agricultural activities and are an important labour force for many countries. It is anticipated that $45.3 \%$ of the agricultural labour force in developing countries consists of women (Ghosh and Ghosh 2014). Thus, the relevant stakeholders should improve women participation in the agricultural sector, as their contribution is vital in order to ensure the sustainability of the sector in near future. In this light, many researchers have conducted studies pertaining to coastal communities' participation in seaweed cultivation activities or other agricultural economic activities globally. Interesting socio-economic impacts from agricultural economic activities to coastal communities have been well documented in previous literature. Using secondary data sources, Ghosh and Ghosh (2014) found that there is an active participation of women in agricultural activities in India except in the states of Kerala, Punjab and West Bengal. The authors also claimed that women's participation in the agricultural sector is recognised and are acknowledged as "agricultural worker". This finding is unique, as previously, women's contributions are not recognised compared to men. This is because women are commonly perceived as unproductive labour in the agricultural sector and often bonded to the cultural norms that value female seclusion and undervalue female labour (Kabeer 1994; Sanzidur 2000; Sraboni et al. 2014). Such discouragement and negative perception make women passive in development projects and limit their participation. Begum and Yasmeen (2011) reported that there are few major constraints faced by women in the agricultural sector, including (1) poor health and malnutrition, (2) lack or complete absence of education, (3) ignorance for using the latest means of agriculture, (4) lack of land ownership and access to credit facilities, (5) lack of segregated economic policy and reforms, (6) natural environment, (7) migration, (8) replacement of females by technology, and (9) low skills and low pay. Such challenges and constraints faced by women in the agricultural sector remain similar and continuously happen in many developing countries.

Based on the literature, it could be observed that women's participation in seaweed cultivation has brought significant implications to their daily lives as well as help the growth of their country's economic revenues. For instance, capacity-building programmes introduced as part of seaweed cultivation projects have significantly recognised women's role in seaweed production and provide them with the opportunity to enhance their skills and knowledge on seaweed 
cultivation methods. Bindu (2010) indicates that the local government in Kerala has played a role in establishing agencies and organised programmes such as Self Help Groups, Kudumbashree under the Panchayat Raj, and Local Self Government Administration, which offer good recognition to women who are engaged in seaweed cultivation. Such initiatives could inculcate interest in women to continuously work in seaweed cultivation activities within their region and provide a chance to improve their livelihoods rather than being fully reliant on fishing activity only. Another study carried out by Eranza et al. (2015) reported that women's participation in seaweed cultivation in the Regency of Jeneponto, South Sulawesi, Indonesia has brought positive impacts. Using the Logistic Regression Model, the study revealed that the variables which were significant in explaining women participation in both paid (when the women work at farms owned by relatives) and unpaid (working at their husbands' or brothers' farm) working environment at 10\% significance level are AGE, WRKPER (number of family members in labour market) and HSYINC (monthly household income including remittance). In addition, Neish (2013) conveyed his compliments and praised women's role in seaweed farming in Indonesia by reporting, "women generally play an important role in seaweed farming. As a result, they sometimes become the main earner in the household, even if initially they had very little income" (p. 81). In this regard, in the context of both developed and developing countries, such compliments are really needed and welcomed at present where it indicates encouragement for the women to be involved in seaweed cultivation with more enthusiasm.

In addition, Hurtado (2013) acknowledged that women play an important role in seaweed production in the Philippines. She claimed that women are seriously involved in seaweed cultivation with their family members in several farming areas in the Philippines, including Tictauan Island, Pangapuyan, Panyam, Layag-Layag, and Arena Blanco, Zamboanga City. It was observed that women are generally perceived as a tool of cooperation and co-production rather than as competition, which causes conflicts with their family members, especially their husbands (Hurtado 2013). In the meantime, the study by Msuya (2013) provided some useful insights on women participation in seaweed cultivation in Tanzania. Msuya (2013) mentioned that seaweed cultivation in Tanzania is a more female-oriented activity because men are often discouraged by the labour-intensiveness and relatively low profitability of seaweed farming. The men prefer other economic activities such as fishing, tourism and shell polishing trade. Women, on the other hand, have limited alternatives and thus put more effort into farming. She also reported that seaweed cultivation is a mainly female-oriented economic activity, which generates low profit. According to the study, which was focused on the Tanga district located in Tanzania, a young male farmer allegedly stopped operating his seaweed farm, which was reported to have 700 lines because the price of seaweed is of "a female 
price", which means that it can be tolerated by women but not by men (Msuya 2013, 131). The study's findings somehow demonstrate the negative connotation of women's participation in seaweed cultivation but at the same time, women are the most important and successful seaweed cultivators in Tanzania.

The study by Kronen (2013) revealed the contributions of women in seaweed production in Solomon Islands, specifically in Wagina Island, Choiseul Province. The study indicated that although men account for $68 \%$ of the labour input, women are actively participating in all stages of seaweed cultivation. For instance, women's contributions in cultivation activities (33\%: harvesting, and $34 \%$ : replanting and maintenance) are greater than their contributions in postharvest activities (32\%: drying, 24\%: packaging, and 24\%: selling) (Kronen 2013, 157). In addition, women in two districts in India, namely Mandapam and Rameshwaram districts were reported to have motivated their husbands to engage in seaweed cultivation even though they were working as full-time fisherman (Krishnan and Narayanakumar 2013).

\section{RESEARCH CONTEXT AND METHODS}

In Malaysia, Sabah is the only state which produces seaweed at a commercial scale (26,076 tonnes in 2015) (Adibi et al. 2016), and seaweed cultivation could potentially become one of the contributors to the country's income. Consequently, the Malaysian government has identified seaweed as one of the National Key Economic Areas (NKEA) under the Economic Transformation Programme (ETP). Seaweed was placed in one of the 16 Entry Point Project (EPP). In the year 2010, the Malaysian government introduced the seaweed transformation programme, which focused on community development and new technological methods through scientific knowledge in order to increase the country's seaweed production. Such initiatives acknowledge that the seaweed crop is the most important commodity exported by the country. Forty-six million ringgit was allocated to boost the seaweed industry in Malaysia in 2011 (Majaham 2010). As a result, the seaweed industry in Malaysia, especially in Sabah, gained the transformation status (EPP3) when the Mini Estate System (MES) was introduced with the aim to transform the conventional seaweed cultivation to a new scientific approach. Traditional seaweed cultivation involved old practices, such as tying the seaweed with nylon strings and over drying the seaweed under sunlight that resulted in low-quality seaweed production and less productive seaweed crops. Hence, there was an urgent need to transform the conventional methods of seaweed by introducing scientific knowledge like MES. 
The present study was carried out in two different islands located in the District of Semporna, Sabah, namely Selakan and Bum Bum Islands. There are three study sites - Selakan Village, a small village located in Selakan Island; Look Butun; and Gellam-Gellam in Bum Bum Island. The composition of human population in both islands can be classified to be predominantly made up of the Bajau ethnic group, who are traditionally known as "sea nomads". They have been living on the islands for decades and perform seaweed cultivation as either their main or secondary economic activity. Generally, for decades, they were reliant on fishing and only in the 1970s did they start to focus on seaweed cultivation as their main livelihood activity for survival. These costal-communities demonstrate good skills in seaweed cultivation and could predict the suitable climate. The income received from seaweed and fishing is somehow less sustainable but they still engage in these activities as there are no alternative jobs available for them. They demonstrate a profound interest in fishing and seaweed cultivation, which encouraged them to engage actively in this programme. One of the driving factors for this is that the income from these activities is mainly used for their daily expenses including schooling of their children. Both islands were chosen as study sites as the local community of both islands have been involved in seaweed cultivation since the 1970s and are deemed to be in the best position to provide data for this study.

Universiti Malaysia Sabah (UMS), a local public university in Sabah was given the responsibility to manage the MES programme systematically. Dr Suhaimi Md. Yasir was appointed as the leader of this project. The two phases of MES started in 2010 and both phases were run concurrently; the first phase (2010-2011) focused on the initial development of MES infrastructure, appointing leading companies who have the stake in seaweed cultivation and the identification of seaweed cultivation farms. Semporna district was identified as a suitable place for seaweed production. The second phase (2013-2020) focused on the development and marketing of seaweed-based products. It is aimed that the MES programme could increase the productivity of seaweed and could produce 150,000 metric tons of high quality processed seaweeds worth up to RM1.45 billion by the year 2020 (New Straits Times 2013). Meanwhile, the Cluster System (CS) was implemented subsequent to the MES. It is considered as a branch of MES as it is also focused on the production on a commercial basis rather than for domestic use. The participants of the CS programme include community members that have already been engaged in seaweed cultivation activities. The initial areas selected for cultivation are Bum-Bum Island, Silungan Island and Merotai Island which located in the district of Semporna, Sabah, Malaysia, but the researcher decided to focus on Bum Bum Island as there are many members of the local community that 
are active in seaweed cultivation, outnumbering the number of cultivators in other islands. CS is managed by the Sabah Fisheries Department. In this light, CS fully involved the local seaweed cultivators under their own cooperative enterprises, which are mainly controlled by the locals and supported by the Sabah Fisheries Department (SFD). The Sabah government, through SFD, has assisted the seaweed cultivators to run their seaweed farms systematically. However, at the same time, seaweed cultivators are fully reliant on the government and this creates a sense of dependency.

This study applied the pure qualitative research approach, which is considered as an appropriate means for understanding individual perceptions (Yin 2003). The aim of this study is to understand the motivation factors contributing to women's participation in seaweed cultivation and the impacts of seaweed interventions (MES and CS) introduced by the Malaysian government. Triangulation technique was used by collecting and analysing data from multiple sources to reduce bias when one relies only on a single source of data. A series of face-to-face in-depth interviews were conducted to collect primary data. In addition, field observations and review of secondary data obtained from a variety of sources especially government reports and websites were used in this study. The fieldworks were carried out between 2012 and 2017 for data collection while interview sessions were conducted with women participating in seaweed cultivation activities in both islands. Fifteen women (see Table 1), a project coordinator of the MES programme and a government official from Semporna Fisheries Department (see Table 2) were purposely selected from both islands. These women have decades-long experience in seaweed cultivation and are deemed to be in the best position to provide insights required for this study (Sekaran 1992). To get additional information on each programme's practical implications, two MES and CS project coordinators or managers and a government official were interviewed. All of the interview sessions lasted for 90 minutes and were tape-recorded. Prior to each interview session, an appointment was made with women participants to invite them to participate and to clearly explain the research purpose. Fifteen women who are actively participating in seaweed cultivation agreed to participate in this study and pseudonyms were used to provide a basis to get to know the informants. The subsequent interviews were held at their homes. To ensure flexibility and develop a rapport with each local community, the authors stayed at study sites for two weeks of data collection. This encouraged the informants to provide truthful answers and the interviews could be done at their convenience without disrupting their daily schedule for domestic works and seaweed cultivation activity. The field observations were also carried out while the researchers were staying at the homes of villagers in both islands. The observations were focused on the women's daily engagement in seaweed cultivation activities and their level of commitment to the 
activities. Moreover, field observation data can supplement the main qualitative data of this study. After the interview sessions, the raw data were transcribed, thoroughly reviewed and compared; and major themes were identified and categorised according to the objective of the study. Finally, interview results were then crosschecked with researchers' field notes and information from secondary sources.

\section{Profiles of Informants}

Both Bum Bum and Selakan Islands are located in the district of Semporna, Sabah and a majority of the island communities are involved in fishing and seaweed cultivation as main economic activities. Table 1 depicts the profiles of women informants from both Bum Bum and Selakan. It was found that the women cultivators in both islands are young, ranging from 17 to 35 years old. Age is one of the factors that indicate one's ability to perform seaweed cultivation even though having responsibility as domestic worker at the same time.

It was observed that the majority of the informants obtained formal secondary education, which helped them to understand and "get to know" the new technological methods in seaweed cultivation provided by the government through the MES and CS programmes. It is evident that the informants have received improvement in their monthly income below RM1,500, which could assist them directly to secure their livelihoods. However, the income received from the seaweed cultivation is still insufficient for their daily survival. It is important to ensure that the sustainability of the MES and CS programmes is to provide side income to the women even though the amount is small. Table 2 indicates the profile of informants from the MES programme and a research officer from the Semporna Fisheries Department. These two informants have knowledge about the both MES, CS programmes in District of Semporna, and their views are used to complement the main data from the women informants. 
Velan Kunjuraman et al.

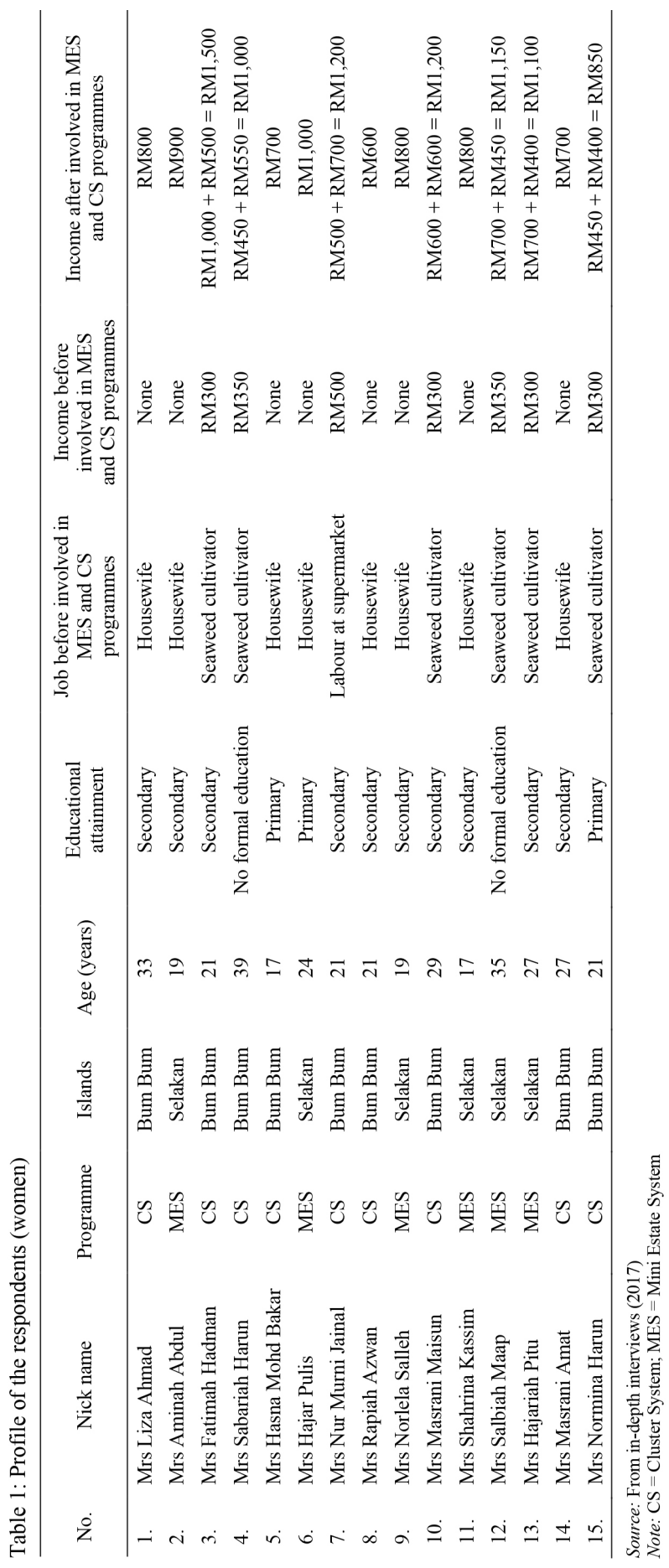


Table 2: Profile of respondents (Programme Coordinator and Government Official)

\begin{tabular}{cccc}
\hline No. & Nick name & Position & Age (years) \\
\hline 1. & Mr. Shahmin Rizal & $\begin{array}{c}\text { Research Officer at Semporna Fisheries } \\
\text { Department } \\
\text { Coordinator of MES }\end{array}$ & 29 \\
2. & Mr. Khalid Azwan & 27 \\
\hline
\end{tabular}

\section{FINDINGS}

The results of the study indicate that the women seaweed cultivators have shared their views pertaining to motivation factors for participating in seaweed cultivation activities. There are few key benefits received by women participants through MES and CS as follows:

\section{Enhancement of Knowledge and Skills through New Technological Interventions in Seaweed Production}

Seaweed as a mechanism to enhance the socio-economic status of coastal communities in Sabah, Malaysia. In this light, Euchema Cottonii and Kappayachus Alvarezii seaweeds are perceived as the potential crops that could provide the opportunity for local communities to generate sustainable income from the sea. Since the 1980s, the Department of Fisheries Malaysia has been involved in seaweed cultivation and has provided support to the local communities with knowledge and skills. The improvement to the conventional seaweed cultivation method has been introduced to enhance the potential of seaweed production (a quality of yields). MES and CS are the two latest seaweed cultivation intervention introduced. Seaweed cultivation through MES and CS could reduce the total of the labour force at sea to $20 \%$ and the remaining $80 \%$ of labour will be on the platform as opposed to conventional cultivation methods where the cultivators will spend more time at sea. These changes make seaweed cultivation more flexible and provide benefits for the cultivators and other stakeholders. These benefits are not enjoyed by the men involved, but by women in the community who are given the opportunity to participate actively in seaweed cultivation activities.

In the traditional convention, women's roles are only focused on having children and taking care of their husbands and family members. On the other hand, MES and CS encourage women to participate in seaweed cultivation and provide a chance to generate income and gain knowledge. MES and CS provide the opportunity for women to participate and attend workshops and learn about the new technologies related to seaweed cultivation. However, such skills workshops 
are not consistent and often conducted "ad hoc". As a result, the project participants, especially newcomers, did not gain sufficient skills and experience in seaweed cultivation activities.

It could be observed that in both MES and CS, women are the majority cultivators in the production of seaweeds (see Photo 1). This is prominent in the process of separating the healthy and unhealthy seaweeds, whereby this process is conducted by the womenfolk after the harvesting process conducted by the males. Based on the observation and in-depth interviews with the informants, it was found that such activity has been practised for decades by the women and is a norm within the society. The informants agreed that women have great deal of tolerance in separating the healthy and unhealthy seaweeds and they are happy with the task given. It was observed that the women are actively involved in seaweed production as a result of new technological intervention and increase in knowledge. The majority informants agree that the MES and CS have enhanced their skills and knowledge in seaweed cultivation and boost their confidence levels. In addition, MES and CS also provided them with an opportunity to be active in seaweed cultivation even though it is a male-dominated industry. Moreover, continuous encouragement given through MES and CS has helped the women participants to be independent and significant contributors to seaweed production. A woman participant from Look Butun Village, Bum Bum Island shared her views:

Through cluster, we have an opportunity to become involved in seaweed cultivation. Before this, I only help my family and husband to tie and cut the seaweed. I'm not just a helper but a participant in the cluster and not just me but it also helps the women and young fellow here. (Mrs. Liza Ahmad of CS, 26 June 2013)

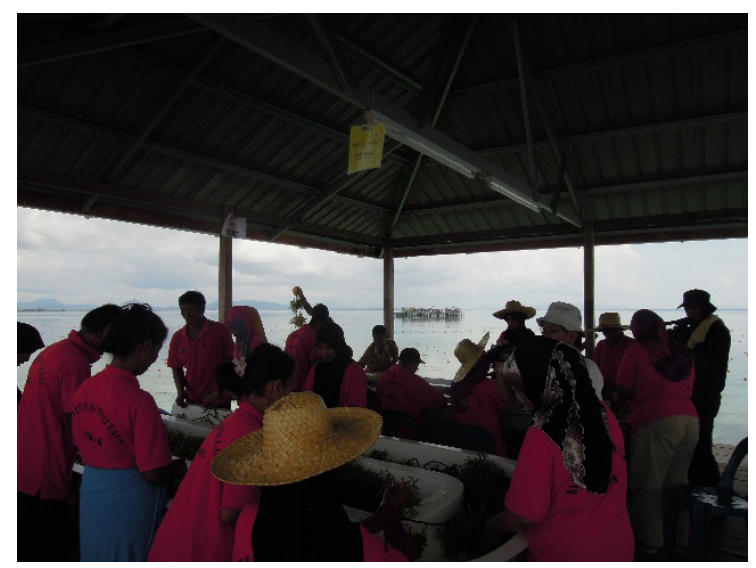

Photo 1: Women participation in seaweed cultivation. 
The high participation of women in seaweed cultivation (not only as a supporting role) is influenced by the changes in seaweed cultivation techniques that allow them to be more systematic, flexible and safer. For instance, in the conventional seaweed cultivation, the women position the seaweeds on top of the boats and floor. This is considered less hygienic and has potential to decrease the quality of the seaweeds. In order to avoid such less hygienic practices, the casino table was introduced and the women were given training on ways to cut the seaweeds appropriately and safeguard the quality of the seaweeds. Such observation from the fieldwork helped the researchers to conclude that the intervention of new technological products in seaweed cultivation were beneficial to produce quality seaweeds as well as change the mind-set of women to give attention on hygiene. The majority of the informants agree that MES and CS help them to be involved freely in seaweed cultivation without disrupting their routine as a homemaker. They are free to do their work and at the same time, be a part of the seaweed cultivation production team. One of the informants shares her view:

Being a housewife, I have a responsibility to take care of my family and I do it every day. Seaweed cultivation activity gives me freedom to perform it anytime. I am always involved in seaweed cultivation activity in the evening after I have done with my family work and sometimes in the morning during my free time. (Mrs. Aminah Abdul of MES, 26 June 2013)

To support the above informant's view, a project coordinator of MES has claimed similarly:

In MES the participant is more to women than man...here, women are more interested to join MES and the work condition is safer and easy... other than that the working hour is similar to office hours $(8$ a.m. to 5 p.m.) and the rest times make the women comfortable and still can do their task at home. (Mr. Khalid Azwan of MES, 12 September 2012)

Through MES and CS, women and other community members are involved in seaweed cultivation, which uses new technological interventions such as detachable eco-friendly long-lines, poly-floats (previously used plastic bottles were used and this had negative environmental impacts), replacing the raffia ties with polyethylene ties, use of anchoring systems, seedling tables (also known as casino tables), wooden drying platforms, fiberglass boats and Malaysian Good Aquaculture Practices (MyGAP) certification scheme under SFD. New methods introduced by the government have influenced directly and indirectly the women participants to be more independent and more innovative in seaweed cultivation. Through these methods, the cultivators learn to cultivate seaweed crops in only 
45 days before selling them to SFD or to Green Leaf Synergy. New technological methods in seaweed production and the use of proper farming techniques helped the seaweed crops to grow healthier and reduce the percentage of damages. The introduction of new technologies such as detachable eco-friendly long-lines, polyfloats (previously used plastic bottles were used and this had negative environmental impacts), replacing the raffia ties with polyethylene ties, use of anchoring systems, seedling tables (also known as casino tables), wooden drying platforms, fiberglass boats are actively used by the informants throughout the process of seaweed cultivation until the harvesting stage. The informants are grouped to help each other in performing the tasks such as tying the seaweeds in poly-floats for production purposes and separating the healthy and unhealthy seaweeds using casino tables. The final stage is the selling task, which is commonly done by the men. However, the researchers in this study observed that some of the informants are also engaged in marketing and selling of seaweeds in their areas. Out of 15 women, two women are actively involved in marketing and selling of seaweeds in the District of Semporna because they are trained by the MES and CS managers. The experience gained by these women differ greatly from other women involved in seaweed cultivation. For instance, these women are motivated to be seaweed entrepreneurs in the village and become a role model to other seaweed cultivators, especially women. Moreover, it is not practical to involve all women in marketing and selling of seaweeds activities because the workforce in seaweed cultivation is still lacking and requires women participation. Thus, two women are selected from the MES and CS managers to perform such task in order to enhance sales of seaweeds in the region (see Photo 2). Several activities as noted earlier done by the informants proved that the women have good control of the technology introduced by the government. In addition, the skills and knowledge have successfully transformed them to become productive workers in seaweed cultivation activities in the study sites.

Women seaweed cultivators work together with men to cultivate the seaweed crops at sea and this has boosted their confidence level (see Photo 3). In this regard, the women are able to perform the same task as the men from the beginning of the cultivation process until harvesting the crops as well as marketing of the products. Such friendly working environment provided through MES and CS interventions creates a platform for the women to enhance their existing knowledge and skills. This statement is supported by the informant:

Now women can join us to do seaweed farming at sea not like before. It helps us to generate income and accelerate time work...by doing seaweed farming through these systems we can do another work and rest. (Mrs. Fatimah Hadman of CS, 26 June 2013) 


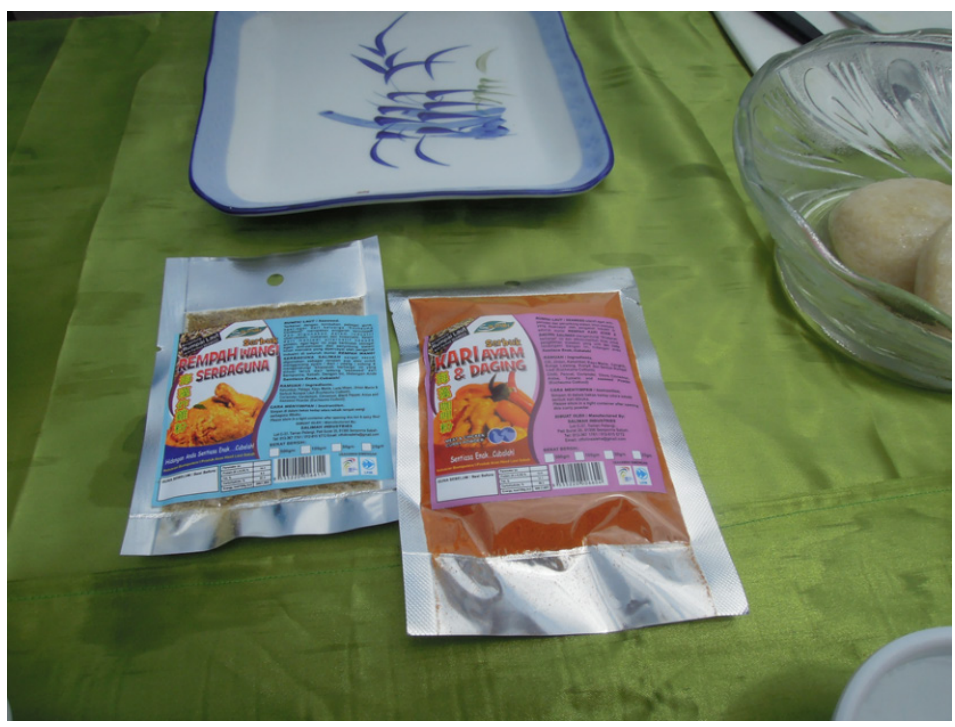

Photo 2: Product based on seaweeds.

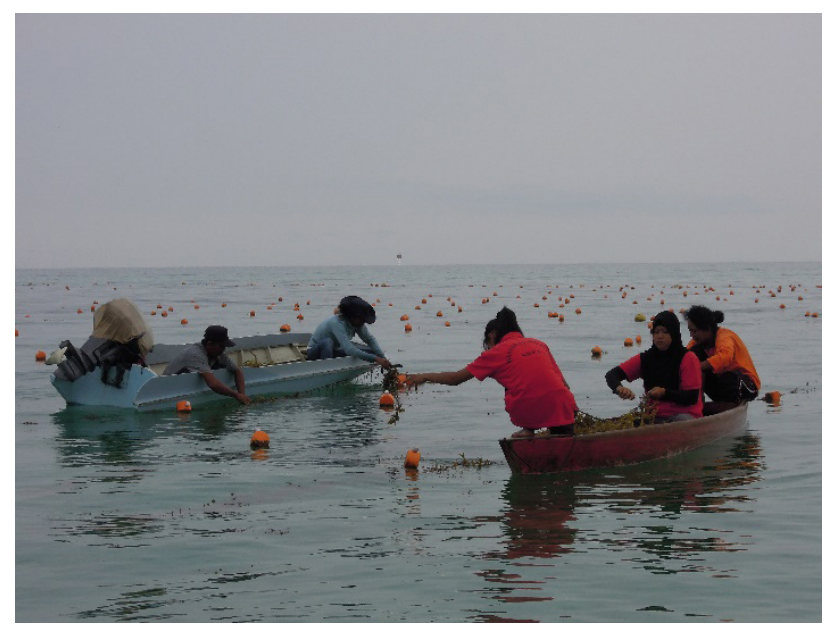

Photo 3: Women together with men to farm the seaweeds.

The impacts of MES and CS are evident in this study as supported by majority of the women participants. They claim that MES and CS provided them with new, scientific-based knowledge. The informants also commented that the programmes have helped them to learn new knowledge about the new scientific approach to seaweed cultivation rather relying fully on conventional methods. On the issues pertaining to the impacts of MES and CS, the programme coordinator of MES commented: 
Previously they (seaweed cultivators) did not have a proper system and $80 \%$ work at sea because the bind seed in seas ... usually only men who could do the job. However, after MES was introduced, women could do work at home and ready to take the seaweed to the sea for hooking it in the farm to increase the production and income. This system requires less energy and is flexible for women. (Mr. Khalid Azwan of MES, 12 September 2012)

\section{Improvement of Monthly Income}

Seaweed cultivation provides an alternative job for some fishermen and villagers around Selakan and Bum Bum Islands. In the context of this study, the informants agreed that the income received from the seaweed cultivation activity was not sustainable due to several reasons. One of these reasons is the fact that traditional seaweed cultivation was done by hiring immigrants from the Philippines, hence, the income obtained would be divided equally between them. However, after MES and CS were introduced, the local community, especially women are given the chance to be involved full-time and the locals do not need to hire immigrants to take care of their farm. This has given an advantage to women to generate steady monthly income and has helped to increase their family income. Furthermore, in addition to the income from the farm itself, women participants of the MES and CS programme are given an allowance of around RM300 (CS) and an average of RM700 per month (MES) as a salary. This is supported by one of the informants:

By participating in this system, we [women] could get some money and have a job. With low education and few job in this village we [women] just stay at home and do nothing. Therefore, seaweed cultivation could generate income. I can help my family to buy food or household needs. (Mrs. Hajar Pulis of MES, 18 December 2013)

This salary is one of the factors that encouraged the women to be involved in this industry as their participation is supported by their husbands and other family members. The participants work in MES farms at office hours ( 8 a.m. to 5 p.m.) while those participating in CS have flexible working hours. However, for planting, they often choose to work early in the morning to avoid hot weather and could do other works later in the day. Furthermore, the participation of women in seaweed farming means that the men could continue to be a fishermen and do other productive jobs. As a result, the monthly household income increases and each family would have some balance for savings. 


\section{Enhance Awareness to be Involved in Multiple Business Opportunities}

The drive to live a better life in the future has encouraged the women participants to do something beneficial for themselves and their family. Consequently, their participation in the MES and CS programmes has provided them with business opportunities. The workshops and seminar about product processing were organised by UMS and Department of Fisheries Sabah to teach how to make seaweed-based beauty products such as soaps and scrubs. Through attending various workshops and seminars about seaweed, the women are learning how to conduct business of seaweed related products in their home islands. As a result, the women have started selling unprocessed seaweed (raw seaweeds) at night markets near their residential areas and also other seaweed-based products. This statement is supported by one of the informants:

By attending the workshops and seminar, we were exposed to the skills and knowledge of the product that can be produced from seaweed. This indirectly provides knowledge and business opportunities for us. We can learn the process of production of seaweed-based products such as curry, pickles, masks, water, seaweed and homemade fish cake from seaweed and try to do it at home. Later, we sell them around the village and outside of village ... from there we can get money and save it ... (Mrs. Masrani Maisun of CS, 18 December 2013)

It is worth to note that even though Semporna is the largest district in Sabah and has a potential to crop and market quality seaweeds, these products could be sold in small amounts. However, the products could not be exported outside of the Semporna vicinity as the participants do not preserve the seaweed, and there is no approval from the Ministry of Health. Thus, the products are packaged in small, attractive and neat packaging to entice customers. The participants also produce samples in small batches and accept product bookings. In the meantime, some of the women participants have applied for loans to help them venture into a wider market and develop their products to a higher level. The Fisheries Development Authority of Malaysia (Lembaga Kemajuan Ikan Malaysia, LKIM) also provides entrepreneurship guidance to show the participants ways to promote and market their products in supermarkets within Semporna.

In addition, the observation data indicated that the women enjoyed the workshop and seminar organised by the authorities. Participating in such business and capacity building workshops not only enhances their current knowledge about seaweed related products and cultivation techniques but also provides them with new perspectives for achieving a better life and enjoy better socio-economic development. 


\section{Increase in the Systematic Management of Seaweed Cultivation Compared to Conventional System}

Seaweed cultivation through MES and CS has helped the local seaweed cultivators to increase their knowledge of the systematic management of seaweed cultivation to replace conventional methods. Working with their family members and near their home, the women participants feel safer and this can help them to organise their work with no disruption. Systematic management is largely stressed in MES and CS and this can increase the production of seaweed to meet the market demand. The local communities were also exposed to the Sanitation Standard Operating Procedure (SSOP), which helps them to maintain their farming and seaweed processing equipment in a sanitised condition. The seaweed crops are harvested using a system based on the practice for aquaculture (Code of Practice, COP) to achieve the MS 2467: 2012 (seaweed cultivation COP) standard. In this light, the operating procedure can help the participants of MES and CS to increase their knowledge of management. As indicated by a government official as follows:

It's a kind of work in the office [SSOP] ... any work or project must not exist if there is no SOP ... SOP's main kinds of projects do go willingly plunge ... SOP is a work procedure that has to plan the work and make it more systematic, for example in seaweed farming the participant must have some kind of file with the table about the implementation of work and the work that has done. (Mr. Shahmin Rizal from Fisheries Department in Semporna, 19 December 2013)

At the work platforms, a schedule for the division of labour has been developed to ensure the platform is kept in clean condition. Each participants' attendance is recorded to ensure that all the participants work as scheduled. In the traditional system, seaweed cultivation was done in the participants' own time and systematic management was not taken seriously when planting the crop; this lowers the quality of the seaweed crops and they could not be sold at higher price. As a result, seaweed cultivators only managed to recover their capital and did not enjoy any profits. This is consistent with the statement of one of the informants as follows:

The first day we clean the seaweed from the rope before sending to buyers ... before engaging in this system, the price offered by the factory for our seaweed is low ... we have to clean the seaweed because we cannot leave the raffia string there because chemicals can cause them to say it was not good quality and bring the price down ... there remains an inherent need to isolate it so that we can sell at a high price. (Mrs. Normina Harun of CS, 18 December 2013) 
Meanwhile, the MES programme coordinator views this situation as follows:

What we expect for a MES is that we want to improve the quality of Malaysia's seaweed and raise the price (seaweed) because now the price of weed is controlled by an outside agency so we have the goal of price (always) to remain ... for now most agents (wholesalers seaweed) are selling (seaweed) outside (like the Philippines and Indonesia) ... so if we can increase the seaweed and improve the quality, we can demand high price ... that is what we try to teach the farmer through the system. (Mr. Khalid Azwan of MES, 12 September 2012)

Thus, in order to solve this problem, the seaweed cultivators should follow the MES and CS protocol to manage seaweed production systematically. Through these systems, the participants take turns to attend the workshop and seminar about the systematic system for seaweed cultivation. These workshops focus on the quality and hygiene management in seaweed cultivation. After attending the courses, the participants are required to do some reports and present their experiences with other participants. At the same time, they are required to help and teach newcomers by sharing what they have learnt from the workshops and seminars.

\section{DISCUSSION AND CONCLUSION}

This study investigates the factors influencing women's participation in the seaweed industry and the implications of government-led seaweed interventions, such as MES and CS in two selected villages of Selakan and Bum Bum Islands of Semporna, Sabah, Malaysia. The results of the study revealed that women participation in seaweed cultivation is contributed by motivational factors such as enhancement of knowledge and skills through new technological interventions in seaweed production, improvement of monthly income, encouragement for women to be involved in multiple business opportunities and increase the systematic management of seaweed cultivation. Almost all of the women participants have shown positive attitude on their involvement in seaweed cultivation interventions (MES and CS) introduced by the government of Malaysia. Therefore, the introduction of MES and CS in seaweed cultivation in Semporna has transformed the women's views by facilitating the shift from the traditional cultivation methods to new scientific cultivation techniques.

The findings of this study indicate that the MES and CS seaweed interventions programmes are beneficial for women development, particularly in the seaweed industry in Sabah, Malaysia. The application of the empowerment concept is evident where the women informants are engaged actively in seaweed 
cultivation and have access to new technology in seaweed production. The elements of "power to" and "power within" in the empowerment concept are evident in this study where the informants in the study are socially and economically empowered by the new technological intervention of seaweed cultivation. The findings of this study are also in line with other previous literature where seaweed cultivation activity is claimed to contribute to self-development (Hurtado 2013; Msuya 2013; Eranza et al. 2015). Moreover, local government interventions in seaweed cultivation also contributed to the development of local infrastructure, as well as local community development, particularly among women (Bindu 2010). In this case, prior to the introduction of the MES and CS, for decades, the local communities in Semporna had been practising conventional seaweed cultivation methods and the production of seaweed was low. This is due to the low level of technology adaptation in seaweed cultivation and low skilled work force. Moreover, the member of the local communities, especially women, did not engage in capacity building programmes, which led to poor management of seaweed cultivation and the production of lowquality seaweeds. Such problems have been solved after the introduction of MES and CS among the seaweed growing communities in the study sites. The Malaysian government's attention on community development issues in rural areas of Sabah is welcomed with full support by the coastal communities and provided them with valuable experience to be a part of the industry. In the case of seaweed industry in Sabah, the MES and CS provide the opportunity for the island communities to experience new scientific approach to sustainable seaweed production.

From the authors' point of view, the women participants in seaweed cultivation in both islands are partially successful even though few benefits are gained throughout their participation. In order to gain massive positive benefits, few issues such as improved monitoring system by the government, engagement of private sectors in seaweed cultivation and proactive local leadership need to be taken into consideration.

From a planning and development perspective, this study offers few recommendations to relevant stakeholders particularly the government to sustain women's participation in seaweed cultivation in the study sites. First, the government should increase and organise more capacity building programmes related with seaweed cultivation to the participants of both the islands. First, the study found that the previous capacity building programmes were limited and "ad hoc" in nature. As a result, the participants were not able to learn important knowledge on seaweed cultivation. They believe that more capacity building programmes such as workshops and seminars (entrepreneurship skills and marketing skills) should be held in their villages. Government agencies should provide some monthly cash incentives to encourage women to participate actively in the programme, even though seaweed cultivation is perceived as an unpredictable source of income. The local leadership of both islands play an important role in encouraging women's 
engagement in seaweed cultivation activities. The study found that even though the community members generate strong capital, it is highly unpredictable. Thus, local leaders, especially community leaders and members of the Majlis Pengurusan Kemajuan Kampung (previously known as Jawatankuasa Kemajuan dan Keselamatan Kampung, JKKK) should build a good rapport with the participants, especially women. Finally, women should be given the chance to develop "women seaweed organisation" within their local community to build a sense of belonging among them. Such initiative will increase their confidence and provide a good start for them to be fully integrated into the decision-making processes related to seaweed cultivation. The above-mentioned recommendations could be realised if the relevant stakeholders are focused on introducing new scientific approaches in seaweed cultivation. At the same time, the future of the seaweed industry in Sabah relies on the cooperation of the local communities.

There are several limitations of this research. This study only explored the factors influencing women participation in the seaweed industry and the implications of government-led seaweed cultivation interventions, such as MES and CS in two selected villages of Selakan and Bum Bum Islands of Semporna., The positive participation by women in seaweed cultivation is the focus of this study but the challenges faced by the women participants in both programmes (MES and CS) were not discussed. Thus, future research is needed to overcome this limitation. In addition, the sample of this research comprises local women and it could be difficult to generalise the outcome. Hence, future research should involve a larger number of women from other parts of Semporna and the state of Sabah for a broader context (Kunak, Kudat and Lahad Datu). Other stakeholders such as the private sectors should also be involved to gain more insights about the issue. Such attempts are needed to enrich the existing body of knowledge pertaining to seaweed cultivation, particularly in Sabah, Malaysia as well as other areas where seaweed is cultivated for economic purpose.

\section{ACKNOWLEDGEMENTS}

The research was supported by the Seaweed Research Unit, Faculty of Science and Natural Resources, Universiti Malaysia Sabah (UMS) under the Research Grant No: GL00045/GPRL/SE/2. 


\section{REFERENCES}

Adibi M. Nor, T.S. Gray, G.S. Caldwell and S.M. Stead. 2016. Is a cooperative approach to seaweed farming effectual? An analysis of the seaweed cluster project (SCP), Malaysia. Journal of Applied Phycology 26(5): 2323-2337. https://doi. org/10.1007/s10811-016-1025-y

Begum, R. and G. Yasmeen. 2011. Contribution of Pakistani women in agriculture: Productivity and constraints. Sarhad Journal of Agriculture 27(4): 637-643.

Berita Perikanan. 2012. Peruntukan RM8 juta untuk kluster rumpai laut. Bil.83, December.

Bindu, M.S. 2010. Empowerment of coastal communities in cultivation and processing of Kappaphycus alvarezii: A case study at Vizhinjam village, Kerala, India. Journal of Applied Phycology 23(2): 157-163. https://doi.org/10.1007/s10811010-9597-4

Cai, J., Hishamunda, N. and Ridler, N. 2013. Social and economic dimensions of carrageenan seaweed farming: A global synthesis. In Social and economic dimensions of carrageenan seaweed farming, eds. D. Valderrama, J. Cai, N. Hishamunda and N. Ridle, 5-59. Fisheries and Aquaculture Technical Paper No. 580. Rome: Food and Agriculture Organization of the United Nations.

Chee, H.H., Filzah Md Isa, W.H. Cheng, Norashidah Hashim, Jasmani Mohd Yunus and Haim Hilman Abdullah. 2012. Development of women entrepreneurs: The case of Malaysia. World Journal of Social Sciences 2(6): 123-145.

Choo, P.S. and M.J. Williams. 2014. Avoiding pitfalls in development projects that aspire to empower women: A review of the Asian fisheries society gender and fisheries symposium papers. Asian Fisheries Science Special Issue 27S: 15-31.

Eranza, D.R.D., J.M. Alin, Arsiah Bahron and Roslinah Mahmud. 2015. Determinants of women's participation in seaweed farming in the Regency of Jeneponto, South Sulawesi, Indonesia. Mediterranean Journal of Social Sciences 6(5): 43-45. https://doi.org/10.5901/mjss.2015.v6n5s5p43

Gaventa, J. 2006. Finding the spaces for change: A power analysis. IDS Bulletin 37: 23-33. https://doi.org/10.1111/j.1759-5436.2006.tb00320.x

Ghosh, M.M. and A. Ghosh. 2014. Analysis of women participation in agriculture. International Journal of Gender and Women's Studies 2: 271-281.

Hossin, A., A.T. Abdul Rahman, R. Hussin, N.I. Kanyo, N. Salleh, B.A. Tamring, S. Yasir and N. Rosli. 2013. Woman participation in seaweed industry in Semporna. Proceeding of 1st International Conference on Human Capital and Knowledge Management, Menara Razak, Universiti Tekonolgi Malaysia, Kuala Lumpur. 3-4 December. https://doi.org/10.30880/jtmb.2018.05.02.005

Hurtado, A.Q. 2013. Social and economic dimensions of carrageenan seaweed farming in the Philippines. In Social and economic dimensions of carrageenan seaweed farming, eds. D. Valderrama, J. Cai, N. Hishamunda and N. Ridler, 91-113. Fisheries and Aquaculture Technical Paper No. 580. Rome: Food and Agriculture Organization of the United Nations. 
Kabeer, N. 1994. Women's labor in the Bangladesh garment industry: Choices and constraints. In Muslim women's choices: Religious belief and social reality, eds. C. Fawzi El-Solh and J. Mabro, 164-183. Oxford, UK: Berg Publishers. https:// doi.org/10.1017/s0041977x00013203

Krishnan, M. and R. Narayanakumar. 2013. Social and economic dimensions of carrageenan seaweed farming in India. In Social and economic dimensions of carrageenan seaweed farming, eds. D. Valderrama, J. Cai, N. Hishamunda and N. Ridler, 163-185. Fisheries and Aquaculture Technical Paper No. 580. Rome: Food and Agriculture Organization of the United Nations.

Kronen, M. 2013. Social and economic dimensions of carrageenan seaweed farming in the Solomon Islands. In Social and economic dimensions of carrageenan seaweed farming, eds. D. Valderrama, J. Cai, N. Hishamunda and N. Ridler, 147-161. Fisheries and Aquaculture Technical Paper No. 580. Rome: Food and Agriculture Organization of the United Nations.

Majaham, E. 2010. Seaweed estates taking shape in Sabah. BERNAMA. http://education. bernama.com/index.php?sid=news_content\&id=532587 (accessed 10 January 2017).

Msuya, F.E. 2006. The impact of seaweed farming on the social and economic structure of seaweed farming communities in Zanzibar, Tanzania. In World seaweed resources: An authoritative reference system, eds. A.T. Critchley, M. Ohno and D.B. Largo, 2-27. Amsterdam: ETI BioInformatics. https://doi.org/10.1007/97894-011-1998-6_44

2007. Combating Kappaphycus die-offs in Tanzania. Forum Phycologicum 66: $2-4$.

2013. Social and economic dimensions of carrageenan seaweed farming in the United Republic of Tanzania. In Social and economic dimensions of carrageenan seaweed farming, eds. D. Valderrama, J. Cai, N. Hishamunda and N. Ridler, 115-146. Fisheries and Aquaculture Technical Paper No. 580. Rome: Food and Agriculture Organization of the United Nations.

Neish, I.C. 2013. Social and economic dimensions of carrageenan seaweed farming in Indonesia. In Social and economic dimensions of carrageenan seaweed farming, eds. D. Valderrama, J. Cai, N. Hishamunda and N. Ridler, 61-89. Fisheries and Aquaculture Technical Paper No. 580. Rome: Food and Agriculture Organization of the United Nations. https://doi.org/10.1007/978-3-319-63498-2_12

New Strait Times. 2013. UMS introduces seaweed mini estate project in Semporna. 4 July. Robledo, D., E. Gasca-Leyva and J. Fraga. 2013. Social and economic dimensions of carrageenan seaweed farming in Mexico. In Social and economic dimensions of carrageenan seaweed farming, eds. D. Valderrama, J. Cai, N. Hishamunda and N. Ridler, 185-204. Fisheries and Aquaculture Technical Paper No. 580. Rome: Food and Agriculture Organization of the United Nations. https://doi.org/10.5539/ ass.v1 $1 \mathrm{n} 18 \mathrm{p} 1$

Rosazman Hussin, Suhaimi Md. Yasir Kunjuraman, V. and Aisah Hossin. 2015. Enhancing capacity building in seaweed cultivation system among the poor fishermen: A case study in Sabah, East Malaysia. Asian Social Science 11: 1-9. 
Rowlands, J. 1997. Questioning empowerment: Working with women in Honduras. Oxford: Oxfam GB.

Safari, S. 2015. Prospects and policy review of seaweed as a high-value commodity in Malaysia. http://ap.fftc.agnet.org/ap_db.php?id=430 (accessed 10 June 2016).

Sanzidur Rahman. 2000. Women's employment in Bangladesh agriculture: Composition, determinants, and scope. Journal of Rural Studies 16(4): 497-507.

Sekaran, U. 1992. Research methods for business: A skill building approach. 2nd ed. New York: John Wiley and Sons. https://doi.org/10.1016/s0743-0167(00)00006-1

Sraboni, E, H.J. Malapit, A.R. Quisumbing and A.U. Ahmed. 2014. Women's empowerment in agriculture: What role for food security in Bangladesh? World Development 61: 11-52. https://doi.org/10.1016/j.worlddev.2014.03.025

United Nations. 2016. Millennium development goals. http://www.un.org/en/index.html (accessed on 1 June 2016).

Valderrama, D., J. Cai, N. Hishamunda and N. Ridler. 2013. Social and economic dimensions of carrageenan seaweed farming. FAO Fisheries and Aquaculture Technical Paper No. 580. Rome: Food and Agriculture Organization of the United Nations.

Yin, R.K. 2003. Case study research: Design and methods. 3rd ed. Thousand Oaks: Sage Publications. 